\title{
The Review of Empirical Researches on IT Investment Announcements
}

\author{
on the Market Value of Firms
}

\author{
Lu Zhang \& Jinghua Huang \\ School of Economics and Management, Tsinghua University \\ Beijing 100084, China \\ Tel: 86-10-5153-4734 E-mail: zhang12.03@sem.tsinghua.edu.cn
}

The research is financed by the National Natural Science Fund (No.70831003, 70621061, 70772022) and the important project of humanistic key research base of Chinese Ministry of Education (No.06JJD630014). (Sponsoring information)

\begin{abstract}
With the advent of the information age, the importance of IT investment becomes more and more obvious for the survival and development of enterprise, and IT has been the important part of enterprise management, so it is very important to understand the impact of IT investment on the performance of enterprise. Through reviewing and analyzing foreign and domestic empirical research literatures about the influences of the IT investment announcements on the enterprise market value, the influencing factors of IT investment value were divided into IT investment character, organization factor and exterior environment, and the limitations of existing research and future research directions about each factor were studied in the article. Aiming at the disputes about the impact of IT investment on enterprise risk and the methodology, the limitations about existing risk factors and methodology were summarized. This article is an attempt to help scholars to further understand the status and limitations of relative researches. Especially, the status of foreign researches was completely explained in the article, and Chinese scholars could further study Chinese sample data aiming at the limitations of existing researches based on the advantages of foreign researches.
\end{abstract}

Keywords: IT investment, Value of IT investment, Market value of firms, Event study

\section{Introduction}

With the advent of the information age, the importance of IT investment becomes more and more obvious for the survival and development of enterprise (Bharadwaj, 2000, P.169-197), and it is very important to understand the impact of IT investment on enterprise performance (Hayes D C, 2001, P.3-18). Up to now, there are many researches to try to establish the relationship between IT investment and enterprise performance (Im K S, 2001, P.103-117). The recent research results indicate that when IT investment with specific attention enters at the proper opportunity and can acquire better management and proper mutually complementary investment, it will produce more business values (Barua A, 2000, P.65-84). Many research methods can be used in relative studies, and event study methodology is one of mature methods (Richardson V J, 2002). The method of event study has been widely used in accounting and financial domain to calculate the impact of specific event on the enterprise market value (Ball R, 1968, P.159-178 \& Brown S J, 1985, P.3-31). In the research domain of IS, the event specially means the IT investment announcement (Richardson V J, 2002). These researches about IT investment return focus on two problems, i.e. (1) whether the IT investment can acquire returns? (2) What conditions the IT investment can acquire the maximum returns (Richardson V J, 2002 \& Dehning B, 2003, P.637-656 \& Oh W, 2006, P.19-44)? In these research literatures, the enterprise market value is used as the index of the IT investment return. For the first question, the conclusions of former researches are not consistent, and some research conclusions showed that the IT investment and the enterprise market value had the positively correlative relationship (Im K S, 2001, P.103-117 \& Richardson V J, 2002 \& Dos Santos B L, 1993, P.1-23 \& Hayes D C, 2000, P.109-125 \& Meng Z L, 2007, P.737-745), but other research conclusions found that there was no significant relationship between them (Hayes D C, 2001, P.3-18 \& Oh W, 2006, P.19-44 \& Meng Z L, 2007, P.737-745 \& Chatterjee D, 2002, P.7-42 \& Dardan S, 2006, P.100-111 \& Dewan S, 2007, P.370-394 \& Lee H G, 2002, P.41-56 \& Oh W, 2006, P.271-303 \& Ranganathan C, 2006, P.145-161 \& Subramani M, 2001, P.135-154). The second research problem tried to explain the source of inconsistent impact of IT investment and answer when IT investment was efficient. 
Aiming at these two problems, relative literatures in recent years were reviewed in the article, and the intention of this article is to help scholars to further understand the status and limitations of relative researches. Especially, the status of foreign researches was completely explained in the article, and Chinese scholars could further study Chinese sample data aiming at the limitations of existing researches based on the advantages of foreign researches.

Or the collection of literatures, the "information technology" or "information systems" or "E-commerce" or "E-business" and "announcement" were used as the keywords to search all databases in ISI Web of Knowledge, and 206 relative article were found, and 24 articles in them were selected by checking and eliminating improper articles. Because the embodying starting times of SCI-Expanded and SSCI in ISI Web of Knowledge were the year of 1994 and the year of 1998, and for the literatures before 1998, the existing reference literatures were elected, and 25 relative literatures from 1993 to 2007 were chose finally.

In the article, the theoretical bases of these literatures will be reviewed systematically, which will help scholars to more understand relative theories in these articles and establish the base for better applying these theories and analyzing the IT investment. The research range and research conclusions of existing literatures can be more clearly understood, and the limitations of existing literatures about the influence of IT investment value can be summarized more clearly though analyzing these literatures from the view of research object. By comparing and analyzing the research methods in these literatures, the limitations of the methodology in existing researches can be deeply understood, which can help relative scholars to further improve the methodology.

\section{Theoretical bases}

Many theories were used to study the impact of IT investment on enterprise value by researchers, and they are introduced as follows.

\subsection{Efficient market hypothesis}

The research of the efficient market hypothesis can be traced to the year of 1889, and economist Gibson described the basic idea of this hypothesis in the book of "Stock Markets in London, Paris and New York". Fama was the expert of this theory, and he made excellent contributions to form and perfect this theory. Fama systematically summarize past researches about the efficient market hypothesis, and put forward a complete theoretical frame to study the efficient market hypothesis (Fama E F, 1970, P.383-417). After that, the efficient market hypothesis developed quickly, and its connotation was continually deepened and its extension was continually expanded, and it finally became one of major theories in modern financial economics. According to the efficient market hypothesis, in the efficient market, there are many rational investors pursuing maximum benefit, and the interior values of stocks will be embodied by their market prices. After Fama implemented large numbers of empirical analysis to the financial market, he proposed three forms of the efficient market. (1) The weak-form efficient market. It integrates all historical information. (2) The semi-strong efficient market. It could not only reflect the past information, but reflect all existing information in the public. (3) The strong efficient market. It includes the contents of the weak-form efficient market and the semi-strong efficient market, and the insider information. Here, investors can not dominate and influence the formation of price, but make their behavior choice according to appointed prices.

According to the semi-strong efficient market hypothesis, the market price can reflect all public information (Fama E F, 1970, P.383-417 \& Fama E F, 1976 \& Jenson M, 1978, P.95-101 \& Watts R, 1986). Therefore, if one important event such as the IT investment announcement contains the information which can be defined as the signal to change investors' anticipation (Watts R, 1986 \& Holthausen R W, 1990, P.191-208 \& Ziebart D A, 1990, P.477-488), and this event is non-predictable, the abnormal stock price fluctuation relative to this even can be observed. And if the IT investment of the enterprise will impact future incomes, so the stock price will react to the issuance of the IT investment announcement.

\subsection{Resources-based view of the firm}

The resources-based view came of the strategic management domain in the middle of 1980s. Traditional strategic researchers thought that the competition advantage of enterprise roots in the industry and the competitive orientation, so the mode of "structure-strategy-performance" generated in the long-term researches. The resources-based view transferred the view of the enterprise competitive advantage from the exterior of enterprise to the interior of enterprise, and emphasized the effect of interior resources on the competitive advantage in the enterprise. The resources-based view ascribes the difference of enterprise performances to various valuable and heterogeneous enterprise resources and resource combinations (Barney J B, 1991, P.99-120 \& Peteraf M, 1993, P.179-191). Wade and Hulland defined the resource as the asset or capacity which helped to find and respond the market opportunity or threat (Wade $\mathrm{M}$ and Hulland J, 2004, P.107-142). According to the resources-based view, the core competitive force of the enterprise is the source of the sustainable competitive advantage, and the core competitive force roots in the core resource of the enterprise. The resources which can continually produce competitive advantage must possess four attributes including value, scarcity, inimitability and non-substitutability (Melville N, 2004, P.283-313). These attributes of the resource 
compose the layers of the competitive advantage. If the resource is valuable and scarce, the enterprise with the resource can acquire the benefits bringing by the resource, the resource can provide short-term competitive advantage for the enterprise. If the resource is inimitable and non-substitutable, the enterprise can avoid that the competitive opponents imitate and copy the resource, so the advantage of the resource is sustainable (Wade M and Hulland J, 2004, P.107-142).

According to the resources-based view, the valuable, scarce, inimitable and non-substitutable IT resources can create continually competitive advantages for the enterprise. So the differences of IT investment attributes in four dimensions in the IT investment announcement issued by the enterprise will induce that the investors have different anticipations to the continually competitive advantage, and the enterprise has different financial performances and different enterprise market values.

\subsection{Process theory}

The process theory thought that IT would influence the middle business process of the enterprise and be reflected on the financial performance and other performances (Melville N, 2004, P.283-313 \& Barua A, 1995, P.3-23 \& Mooney J G, 1996, P.68-81 \& Radhakrishnana A, 2008, P.1105-1125 \& Soh C, 1995, P.29-41). The so-called enterprise process means the activities performed by the enterprise to achieve the organizational objective, so the enterprise process can be regarded as the activity or route to complete certain task for the enterprise (Nelson R R, 1982 \& Porter M E, 1991, P.95-117), such as the process that the enterprise obtains the raw materials and supplies, the process that the enterprise produces products or provide services, the process that the enterprise transfer the products and services to consumers, and the process that the enterprise provides after services (Porter M E, 1985). The process innovation and the enterprise flow theory (Davenport T H, 1993 \& Hammer M, 1993) provide theoretical references for the association between the middle process and the enterprise performance.

Therefore, on the layer of enterprise, the function of IT to the performance roots in the profits of IT on the layer of operation process. The profits on these process layers include the operation profit (such as the cost savings and the enhancement of interior efficiency) and the strategic profit (such as the improvement of product/service, the further understanding to customers and suppliers) (Mukhopadhyay T, 2002, P.1301-1313 \& Subramani M, 2004, P.45-75). Barua used the process-based method to study the effect of IT on the strategic business unit or the profit center performance, and he thought that the relationship between IT investment and performance decreased with the increase of the middle process, and he also researched the adjustable function of the middle process to the IT-performance relationship in the theoretical model (Barua A, 1995, P.3-23). Soh and Markus put forward the comprehensive process model, i.e. the IT investment produces IT assets (IT transform process) and IT assets produce IT effect (IT use process), and IT effect produces the enhancement of the organizational performance (competitive process) (Soh C, 1995, P.29-41). For the IT investment announcement, investors can anticipate the impact of IT investment on the enterprise business, even on the enterprise performance, which will finally be reflected on the changes of the enterprise market value.

\subsection{Transaction cost theory}

The transaction cost theory was proposed by Coase in 1937, and its essential consists in the explanation of the essential of the enterprise (Coase R H, 1937, P.386-405). Williamson further studied the transaction costs and divided them into two sorts including the before-event cost and the after-event cost (Williamson O E, 1985). Dahlman classified the contents of the transaction activities (Dahlman C J, 1979, P.141-162). The reasons of the transaction cost come from three characters of the transaction, i.e. the specificity of the transaction or the asset, the uncertainty and the transaction frequency, and they compose three layers to impact the transaction cost (Williamson O E, 1985).

According to the transaction cost theory, the assets with strong specific attribute will possess strong dependence on cooperative fellows (including suppliers and consumers), so if any one cooperative fellow only pursue his own maximum profit, the enterprise will produce high transaction cost (Williamson O E, 1979, P.233-261). Domsetz also pointed out that when the supplier's asset fulfilled the special requirement of the enterprise and the loss to terminate the contract was higher than the profit, the supplier would always perform the behavior to maximize his own benefit (Domsetz H, 1988, P.141-161). And the specific attribute of the asset is the important attribute of IT, because most IT resources are private, i.e. they are developed to fulfill the special requirement of the enterprise (Ang S, 1997, P.235-256). The asset with strongly specific attribute is difficult to be used in other intentions. From the view of transaction cost, when the enterprise invests to the IT resource with strongly special attribute, the enterprise will face larger transaction risk, and investors' anticipation to future cash flow will be reduced, and most IT investment projects are uncertain, so it is obvious that the IT investment with high uncertainty will bring larger transaction risk and reduce investors' anticipations to the enterprise.

\subsection{Resource dependence theory}

In 1949, Selznick's classical research to the authorities of the Tennessee Valley offered strong base for the resource dependence theory (Selznick P, 1949). In 1958, Thompson and McEwen confirmed three types of the cooperative relationship among organizations, i.e. the alliance (including alliances such as the joint venture), the consultation 
(including the contract negotiation) and the common choice (Selznick defined it as attracting potential interfering factors to enter into the decision institution of one organization) (Selznick P, 1949 \& Thompson J D, 1958, P.23-31). In 1967, Thompson put forward the power of the comprehensive organization, i.e. the dependence mode (Thompson J D, 1967). Pfeffer and Salancik were the experts of the resource dependence theory, and they thought that the dependence degree of one organization to another organization was decided by three decisive factors, i.e. the important of resource to the organizational survival, the degree that the interior of the organization or one exterior special group obtained or disposed the use of resource, and the existence degree of the replaceable resource source (Pfeffer J, Salancik G, 1978). If one organization needs one kind of special knowledge in the extreme and this kind of knowledge is very rare in the organization and the replaceable knowledge source doesn't exist, the organization will highly depend on other organizations with this kind of knowledge.

Based on the resource dependence theory, the enterprise will exchange resources to maintain the competitive force and reduce the uncertainty (Pfeffer J, Salancik G, 1978). Kern and Kreijger thought that the dependence of resource is the function about the resource value of the enterprise, the selective supplier amount and the conversion cost (Kern T, 2002, P.3-19). Different IT investment projects possess different resource values, selective supplier amounts and conversion costs, so they will have different dependences to the suppliers, and with the increase of the dependence to suppliers, the supervision to the suppliers will be reduced, and the cost of IT investment project may increase and the achievement degree of the anticipative objective will decrease, so the long-term performance and the enterprise market value will be influenced finally. Therefore, the IT investment with higher resource dependence will possess weaker positive impact on the enterprise market value.

\subsection{Real option theory}

The concept of the real option was first proposed by Mysers in MIT, and he pointed out that the traditional discounted cash flow method had its interior limitations when it was used to evaluate the investment opportunity with management flexibility and strategic function, and he applied the concept of option in the real assets, and used the financial option pricing theory to evaluate this kind of investment opportunity (Myers S C, 1977, P.147-176). Keste discussed the strategy and the competitive function of the growth opportunity (Kester W C, 1984, P.153-160). Trigeorgis and Mason pointed out that the evaluation method based on the option pricing theory was the proper method to evaluate the management flexibility and the strategic function for the enterprise (Trigeorgis L, 1987, P.14-21). Trigeorgis, Brealey, Myers and Kulatilaka \& Marcus discussed other general concepts about the real option (Brealey R A, 1991\& Kulatilaka N, 1988, P.183-200 \& Kulatilaka N, 1992, P.92-100 \& Trigeorgis L, 1988, P.145-167).

The management academe has been disputing to use the real option to deal with the uncertain investment of new technology for many years (Dixit A K, 1994 \& Trigeorgis L, 1993, P.1-20). In these researches, the similarity of the real asset option and the option created by the technology-oriented investment was found (McGrath R G, 1997, P.974-996). The technology-oriented investment means the right of the profit created by further developing and implementing the technology. It doesn't mean the obligation, which is similar with the real option. The enterprise implementing this kind of investment keeps the right to enter into higher technology, and if the technology can be proved to be profitable, it can be further actualized, and if the technology can be proved to be non-profitable, the enterprise can limit the loss in the cost of the oriented investment. Some information system researchers thought that part of IT investments could produce values as a kind of digital option, for example, the investment to construct IT platform can expand the organizational flow range by integrating the activities and information flows of the function units, sub-companies and exterior companies (Sambamurthy V, 2003, P.237-263). The investment to the ERP system will create corresponding opportunities for the future E-business or other electric supply chain (Taudes A, 2000, P.227-244). Therefore, as a kind of digital option, some IT investments may produce values, influence the future performance of the enterprise and enhance the enterprise market value by creating opportunities for the future growth of the enterprise.

Except for that, there are other theories which can be used to explain the impact of IT investment on the enterprise market value. Dos Santos et al introduced the concept of "First Mover Advantage", and pointed out that the innovational investment of IT would produce larger profits than the following investments (Dos Santos B L, 1993, P.1-23). Before the competitive opponent imitates, investors can use innovational IT investment to obtain excess return. Starting form the competitive Agility, Chatterjee et al studied and found that the IT infrastructure investments could bring larger investment values than the IT application investments (Chatterjee D, 2002, P.7-42). Based on the theory of the herding effect (Banerjee A, 1992, P.797-817) and Lee's explanations about two concepts including the information follow and the information collapse (Lee I H, 1998, P.741-759), Dehning et al studied the influence of the E-business investment announcement to the enterprise market value in the period of forming and breaking the network bubble (Dehning B, 2003, P.637-656). Sabherwal R and Sabherwal S used the contingency theory, the organizational learning theory and the knowledge-based enterprise theory to find that the abnormal return of the enterprise were significantly associated with the scale of the enterprise, ROS, the cooperation between the enterprise validity and the knowledge management process, the stability of the enterprise, and the diversification of the enterprise (Sabherwal R, 2005, 
P.531-567). Oh et al used the agency theory to explain the agent risk in the IT outsourcing, and explored the influences of IT outsourcing projects on the enterprise market value (Oh W, 2006, P.271-303). Starting from the organizational integration, Ranganathan and Brown studied and found that the ERP with bigger physical scope could produce larger performance (Ranganathan C, 2006, P.145-161). In the researches about the influences of IT investment among countries on the enterprise market value, Meng and Lee introduced the catch-up theory to explain different influences of the IT investments in the developing country and the developed country on the enterprise market value (Meng $\mathrm{Z} \mathrm{L}$, 2007, P.737-745). Dewan and Ren used the organizational learning theory to explain the differences of the influences of the expansive E-business investment and exploring E-business investment on the enterprise market value (Dewan S, 2007, P.370-394). Sabherwal R and Sabherwal S used the contingency theory, the strategic cooperation theory and the knowledge sharing theory to study the influence of the cooperation between the knowledge management announcement and the enterprise knowledge management strategy to the excess return (Sabherwal R, 2007, P.409-422). Lin et al studied the impact of the E-business service announcement on the enterprise market value based on the strategy and marketing theory (Lin J C, 2007, P.224-245).

After the relative theories referred in literatures are introduced, the empirical researches in these literatures will be reviewed as follows.

\section{Review of literatures}

In this part, the research literatures about IT investment announcement will be reviewed, and the contents, conclusions and methodologies of the empirical researches will be introduced as follows.

\subsection{Introduction of empirical researches}

To understand and compare these literatures, these literatures are divided into six sorts according to the research objects. The first sort means the investment announcements about IT, and it generally refers to all investment announcements about IT. The second sort means the E-business announcements, and it mainly includes the announcements that the enterprise develops the E-business activities or expresses its intent to develop the E-business activities. The third sort means the enterprise system announcements, and it mainly includes ERP (Enterprise Resource Planning Systems), CRM (Customer Relationship Management Systems), SCM (Supply Chain Management Systems) and DSS (Decision Support Systems). The fourth sort means the announcements about knowledge management, and it includes the announcements about knowledge sharing and knowledge management systems. The fifth sort means the announcement of IT outsourcing, and it includes the outsourcing announcements of IT/ E-business. The sixth sort means the announcements about IT personnel, and it mainly includes the announcement about IT personnel, managers and CIO. Some empirical researches about these sorts will be respectively introduced as follows.

\subsubsection{Investment announcements about IT}

Researchers used IT, IS (Information systems) and other keywords to search for the investment announcements about IT, and the research conclusions of the investment announcements about IT are inconsistent.

Dos Santos et al used the event study methodology to measure the direct and indirect values of IT investment by test the reactions of the stock market to IT investment announcement. In 97 samples in the manufacturing and finance industry from 1981 to 1988, they had not found any excess return. In cross section analysis, they found that the evaluation to the innovational IT investment in the market was higher than the evaluation to the following IT investment (Dos Santos B L, 1993, P.1-23).

Based on Dos Santos' researches, Im et al used more and new IT investment announcement samples $(1981-1996,238)$ to test the share price effect of the announcement and the change of trading volume (Im K S, 2001, P.103-117). The result of the total samples was similar with Dos Santos' research, which indicated that investors had not positively evaluated IT investment announcement. The change of trading volume was not significant too. They also tested the influences of the industry, the enterprise scale and the announcement time on the share price.

Chatterjee et al studied 112 groups of IT investment announcement data from 1992 to 1995 and found that at the day that the event happened, the stocks always had significantly abnormal return (Chatterjee D, 2002, P.7-42). They also found that the IT infrastructure investment announcement could bring larger excess return comparing with IT application investments.

Based on Dos Santos, Im and Chatterjee's researches, Dehning et al tested the impact of IT strategic role (Dehning B, 2003, P.637-656). They also found that when the enterprise implemented transform IT investment, it would always obtain significant excessreturn.

Dardan et al analyzed the influences of IT investment about clients on the customer satisfaction and the enterprise market value (Dardan S, 2006, P.100-111). Based on 57 samples of 17 enterprises from 1996 to 2001, they found that IT investment about clients could enhance the customer satisfaction and bring significantly abnormal return. Oh et al studied 430 IT investment announcement samples from 1985 to 1999, and found that IT investment announcement 
could bring significantly positive abnormal return for the enterprise. Except for that, they also found that the growth opportunity, uncertainty, IT strategic role, disclosing party, the interaction of uncertainty and strategic role and the interaction of uncertainty and special attribute of asset would all significantly influence the abnormal return of the enterprise (Oh W, 2006, P.19-44).

Meng and Lee studied the data in the US and Chinese Markets from 1999 to 2002, and found that Chinese IT investment announcement had significant abnormal return, but US IT investment announcement was not so (Meng Z L, 2007, P.737-745). They also tested 3 factors which might possibly impact the IT investment value, i.e. the industry, the enterprise scale and the enterprise type.

\subsubsection{E-business}

Researchers mainly collected the announcements of the enterprises which had developed the E-business activities or wanted to develop the E-business activities, and studied the impact of these announcements on the enterprise market value.

Subramani and Walden used the event study methodology and adopted US samples $(1998.10 .1-1998.12 .31,251)$ to study the change of the market value of the enterprises which issued E-business announcements (Subramani M, 2001, P.135-154). They found that the cumulative abnormal return(CAR) of E-business announcement was positive, and the CAR of traditional enterprises and networking enterprises were almost the same, and the CAR of B2B and B2C were significantly different, and the CAR of digital products and tangible products were significantly different.

Using Subramani and Walden's research results for references, Lee et al used Korea samples and combined with the concrete situation of the Korea to implement similar researches (Lee H G, 2002, P.41-56). In these researches, the type of the E-business announcement and the type of the E-business enterprise was expanded, and the E-business announcements were analyzed in two different capital markets (KOSDAQ and KSE). The empirical conclusion indicated that the reaction of the capital market to the enterprise E-business announcement was positive.

Dehning et al found that the traditional event study methodology was not applicable to the period with large fluctuation in the stock market (Dehning B, 2004, P.55-82). They put forward a new method, and used this method to study and find that 251 E-business announcements in the fourth quarter in 1998 could bring significant abnormal return, but 542 E-business announcements in the fourth quarter in 2000 could not significantly influence the stocks. They also found that there were differences between tangible products and digital products, B2B and B2C, traditional announcement and networking announcement for the E-business announcements.

Ferguson et al studied 232 E-business investment announcements in the Australian listed enterprises from 1988 to 2001 and found that the E-business investment announcement would positively influence the market value of the enterprise. In the cross section analysis, they found that non-innovational E-business investment announcements would bring larger abnormal return for the enterprise (Ferguson C, 2005, P.5-29).

Dewan and Ren comprehensively tested the influences of the E-business announcements from 1996 to 2002 on the return and risks of firms(Dewan S, 2007, P.370-394). When the risk change could be controlled, the influences of these announcements on the share price were not significant. In 1998 and 2000, the total risk and non-systematic risk of the enterprise rose significantly, but the systematic risks in 1996 and 2002 reduced. They also found that the enterprise scale, the risk before the enterprise event window, the return before the event window, the product type evolved in the E-business and the time all were significantly correlative with the systematical risk change of the enterprise. The non-systematic risk change of the enterprise was significantly associated with the enterprise scale, the risk before the event window, and the time.

Lin et al studied 179 E-service announcement samples from 1999 to 2002, and found that the enterprise would obtain significantly abnormal return going with the E-service announcements (Lin J C, 2007, P.224-245). They also found that the enterprise scale and the market scale were negatively correlative with the investment value, and the experiences of the enterprise were positively correlative with the market value of the enterprise.

\subsubsection{Enterprise system}

These researches mainly mean the empirical researches about ERP, CRM, SCM and DSS announcements.

Hayes et al studied the reaction of the market to the IT investment with special type, i.e. the ERP system (Hayes D C, 2001, P.3-18). In total, the market positively evaluated the ERP implementation announcement. They also researched the function of the interaction of the enterprise scale and the healthy degree to the market reaction. Except for that, combining with the characters of ERP, the factor of supplier was introduced in the research. The research result indicated that small fine enterprise would obtain higher return, and the known supplier with large scale would also enhance the return of the enterprise.

Ranganathan and Brown studied 116 ERP investment announcements from 1997 to 2001, and they found that these announcements had significantly positive abnormal return in the event window (Ranganathan C, 2006, P.145-161). 
They also used the regression model to test the functional scope and the physical scope of the ERP projects, and the influence of suppliers on the abnormal return, and the conclusion indicated that these the former two variables were positively correlative with the abnormal return.

\subsubsection{Knowledge management}

This sort of research object mainly includes some announcements about knowledge management, and though the knowledge management is one quit important part of the development for the enterprise, but there are few researches about this aspect.

Sabherwal R and Sabherwal S studied the knowledge management announcement based on IT and found that the abnormal return of the enterprise was significantly associated with the scale of the enterprise, ROS, the cooperation between the enterprise validity and the knowledge management process, the stability of the enterprise, and the diversification of the enterprise (Sabherwal R, 2005, P.531-567).

Based on 103 knowledge management announcements from 1995 to 2002, Sabherwal R and Sabherwal S found that the abnormal return was significantly associated with the enterprise scale, the knowledge management strategy, the cooperation degree of the knowledge management strategy and the knowledge management announcement, but was not significantly associated with the knowledge management process, the knowledge management source and users (Sabherwal R, 2007, P.409-422).

\subsubsection{IT outsourcing}

This sort of research object mainly includes the outsourcing activities about the IT, IS and E-business, and researches explain the advantages and disadvantages of outsource to the enterprise by studying the effect of outsourcing announcement on the enterprise market value.

Hayes et al surveyed the abnormal market return of the IT outsourcing announcements, and the research conclusions based on 76 IT outsourcing announcement from 1990 to 1997 indicated that the IT outsourcing announcement could not bring excess return (Hayes D C, 2000, P.109-125). They also found that the enterprise scale was significantly negatively correlative with the excess return, and the service industry could obtain higher excess return

Peak et al studied 64 samples from 1988 to 1993 and found that the value of IT/IS outsourcing in big enterprises was zero, but it would change the risk of the enterprise (Peak D A, 2002, P.6-33). The enterprise with low healthy degree would increase the risk, and the enterprise with high healthy degree would reduce the risk.

Oh and Gallivan studied 97 samples from 1998 to 2001 and found that investors thought that IT outsourcing could produce values (Oh W, 2004). They also found that the value created by IT outsourcing was negatively correlative with the special attribute and the control scale of the IT resource.

Based on 96 E-business outsourcing announcement samples from 1999 to 2002, Agrawal et al found that the E-business outsourcing projects achieving quick reaction could obtain abnormal return, and they also found that even the outsourcing project with high complexity could bring significant excess return for the enterprise (Agrawal M, 2006, P.861-873).

Based on 192 samples form 1995 to 2003, Oh et al's researches indicated that the IT outsourcing announcement was significantly associated with the enterprise market value (Oh W, 2006, P.271-303). They also found that the abnormal return of the enterprise was significantly associated with the industry and the scale of the outsourcing contract, the difficulty of the supervision, the special attribute of the asset, and the scale of the supplier.

\subsubsection{IT personnel}

This sort of research object mainly includes the announcements about IT personnel, managers and CIO. Only for the existing researches, because the information disclosing is only limited in some announcement about the CIO appointment, the existing researches only stayed on the layer of CIO.

Chatterjee et al tested the reaction of the market to the behavior that the enterprise established CIO announcement, and the research result indicated that in the industry with IT strategic transform, to establish the CIO post would significantly enhance the market return for the enterprise (Chatterjee D, 2001, P.43-70).

Khallaf and Skantz studied 461 CIO appointment announcements from 1987 to 2002, and they found that there was not significant difference for the announcement to establish and appoint CIO and for the announcement to appoint CIO (Khallaf A, 2007, P.83-105). They also found that the market would punish the companies which had not obtained potentially strategic advantages of $\mathrm{CIO}$ in time, and tested the reaction of the market to the CIO appointments with different qualities.

After empirical researches in recent years were reviewed, the methodology used in these literatures will be introduced as follows. 


\subsection{Event study methodology}

In above literatures, almost all literatures adopted the event study methodology. The event study methodology is used to discuss the impact of the happening of the event on the share price (or the enterprise market value). In foreign countries, the event study methodology was first widely applied in the financial economic domain, and the literatures about the event study methodology occurred in recent years have been the important part of the financial economic literatures. In addition, the event study methodology is also used out of the financial economic domain.

When designing and selecting the model to compute the normal return and evaluating the happening of the event, the abnormal return produced by single stock is the key for the event study methodology. Researchers must first suppose the anticipated return of single stock without the effect of this event, and use the actual income after the event happens to detract the anticipated income. Campbell et al though the models to compute the normal return mainly included the economic model and the statistical model (Campbell John Y, 1997). Based on the statistical hypothesis of the asset return behavior, the statistical model doesn't depend on any economic theories, and the economic model takes the hypothesis about relative investors as the base, and it doesn't depend on the statistical hypothesis.

\subsubsection{Statistic model}

\section{(1) Constant mean model}

The idea of the model is to take the average return of the stock in the estimation window as the normal return of the stock in the event window. Supposed that $\mathrm{u}_{\mathrm{i}}$ is the average return of the asset $\mathrm{i}$, so the constant mean model is

$$
\mathrm{R}_{\mathrm{it}}=\mathrm{u}_{\mathrm{it}}+\xi_{\mathrm{it}}
$$

$\mathrm{E}\left[\xi_{\mathrm{it}}\right]=0, \operatorname{Var}\left[\xi_{\mathrm{it}}\right]=\sigma_{\xi_{\mathrm{i}}}^{2}$

Where, $R_{i t}$ is the t'th return of the stock $i$, and $\xi_{i t}$ is the interfered item. Though the constant mean return model may be the simplest model, but Brown and Warner found that the result from this model was similar with the results from other complex models (Brown S J, 1985, P.3-31 \& Brown S J, 1980, P.205-258). In addition, Chen Hanwen and Chen Xiangmin's researches indicated that the mean adjustment model had certain advantage in the Chinese market (Chen $\mathrm{H}$ M, 2002, P.40-47).

(2) Market model

The market model is the statistical model which associates the return of certain stock with the combined return of stocks in the market, i.e.

$$
\begin{gathered}
\mathrm{R}_{\mathrm{it}}=\alpha_{\mathrm{i}}+\beta_{\mathrm{i}} \bullet \mathrm{R}_{\mathrm{mt}}+\xi_{\mathrm{it}} \\
\mathrm{E}\left[\xi_{\mathrm{it}}\right]=0, \operatorname{Var}\left[\xi_{\mathrm{it}}\right]=\sigma_{\xi_{\mathrm{i}}}^{2}
\end{gathered}
$$

$R_{i t}$ and $R_{m t}$ respectively are the return of the stock $i$ and the return of the market investment combination in the $t^{\prime}$ th term, and $\xi_{\text {it }}$ is the interfered item. The market model is the model based on the improvement of the constant mean return model. It eliminates the return about the change of the return of the market combination and reduces the variance of the abnormal return, so it may strengthen the ability to test the event effect. The selection of this model is mainly decided by $\mathrm{R}^{2}$ when this model regresses, and $\mathrm{R}^{2}$ is bigger, the eliminated part of the abnormal return variance is bigger and it is more profitable to select this model, v.v. (MacKinlay C A, 1997, P.137-157). Many other statistical models can also be used in the modeling of the normal return. General statistical models belong to the factor model. The market model is the example of the single factor model, but in many multi-factor models, they can also include the industry index except for this factor. Aiming at the statistical character of the share price, Brown and Warner applied the simulated sampling method to prove the good applicability of the market model to the month data and the day data (Brown S J, 1985, P.3-31 \& Brown S J, 1980, P.205-258). They also pointed out that the model should be selected and improved aiming at different periods and markets.

\subsubsection{Economic model}

The economic model is the normal return model which can offer more restrictions. The typical economic models include the capital asset pricing model (CAPM) and the arbitrage pricing model (APT).

After calculating the abnormal return by the selected model, its significance should be tested. The pioneer parameter test hypothesize share pricing behaviors among samples were independent each other, and considering that the clustering character of events may induced the pertinence among samples, Brown and Warner pointed out that it would underestimated the estimated variance in the test variables and put forward one adjustment method (Brown S J, 1980, P.205-258). Beaver, Kalay, Loewenstein and Boehmer et al's empirical researches indicated the variance of the abnormal return might increase because the event happened, and past parameter test variables always underestimated the variance, and more easily reject the original hypothesis without abnormal return (Beaver W H, 1968, P.67-92 \& Kalay A, 1985, P.423-449 \& Boehmer E, 1991, P.253-272). Boehmer (1991) et al put forward the standardized cross 
section test aiming at this phenomenon (Boehmer E, 1991, P.253-272). The statistic used in the literatures involved in this article is

$$
\mathrm{J}_{1}=\frac{\operatorname{CAR}\left(t_{1}, \mathrm{t}_{2}\right)}{\left[\sigma^{2}\left(\mathrm{t}_{1}, \mathrm{t}_{2}\right)\right]^{\frac{1}{2}}} \sim N(0,1)
$$

Where,

$$
\sigma^{2}\left(t_{1}, t_{2}\right)=\sum_{t_{1}}^{t_{2}} \sigma^{2}\left(A R_{t}\right)
$$

And

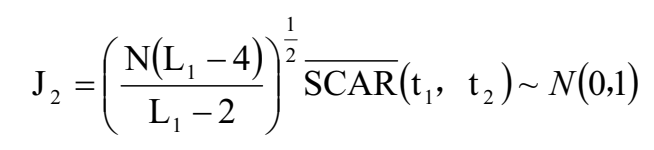

Where,

$$
\overline{\operatorname{SCAR}}\left(\mathrm{t}_{1}, \mathrm{t}_{2}\right)=\frac{1}{\mathrm{~N}} \sum_{\mathrm{i}=1}^{\mathrm{N}} \frac{\operatorname{CAR}_{\mathrm{i}}\left(t_{1}, \mathrm{t}_{2}\right)}{\left[\sigma_{\mathrm{i}}^{2}\left(\mathrm{t}_{1}, \mathrm{t}_{2}\right)\right]^{\frac{1}{2}}}
$$

The non-parameter tests which can be used in the event study methodology mainly include the generalized symbol test, the Wilcoxon symbol order test and the Corrado's rank test. The empirical researches indicated that the distribution of the abnormal return was represented as right-skewed and fat-tailed, and Cowan and Sergeant found that the non-parameter test would be better than the parameter test under this situation. Not only the non-parameter test is better than the parameter test under the decline distribution, but it can be used to find the abnormal values in the samples (Cowan A R, 1996, P. 1731-1757).

After reviewing the empirical researches in these literatures, the limitations and future research directions of the existing researches will be introduced as follows.

\section{Limitations and future research directions}

Though the impact of IT investment on the enterprise market value has been studied from multiple dimensions in existing researches, there are still some limitations. First, the time periods of these samples are too early, so it is further to be validated whether these research results could be applied in present IT investments. Second, certain limitations still exist in following aspects in existing researches.

\subsection{IT investment characters}

Most researches belong to general researches about IT investment or E-business investment, and there are few researches to study concrete IT investment projects, and when the concrete projects are not limited, the special attribute of these concrete projects is difficult to be concretized to measure their influences on the IT investment values. Therefore, various IT investment projects should be concretized, and the character factors and the weights influencing the enterprise market value should be tested aiming at various concrete investment projects (Hayes D C, 2001, P.3-18 \& Im K S, 2001, P.103-117 \& Dos Santos B L, 1993, P.1-23), for example, the ERP system mainly offers a uniform information platform for the enterprise, which can enhance the interior efficiency of the enterprise, save the cost and provide opportunities for the applied development, and CRM system is mainly used to better know customers' favors and achieve higher customer satisfaction, and enhance the performance of the enterprise finally. Both strategic intentions, implementation ranges, implementation times, technologies in the implementation, and the processes to produce the values are not same completely, and the factors which will influence the final values in the value production process are also different, so the attributes of ERP and CRM should be discussed respectively to find out the attributes which may influence the final values based on certain theory.

\subsection{Organization factor}

In the process that the IT investment produces values, the attributes of the enterprise are also very important. Though some empirical researchers introduced the factor of enterprise when measuring the IT investment values, but because of the extensive attributes of IT investment, it is hard to find out which kind of enterprise character will influence which IT investment to the largest extent. When the IT investment type is concrete, the influence of the enterprise character on 
the IT investment value should be systematically analyzed based on relative theories and former empirical research results (Oh W, 2006, P.19-44 \& Dos Santos B L, 1993, P.1-23). For example, the purchase of IT hardware may be nothing with the healthy development of the enterprise, but in the implementation of many large enterprise systems such as ERP, many uncontrollable factors may largely exceed the budget, and if the healthy degree of the enterprise is too low, the capital chain of the enterprise may be broken, and the project may fail. Other researches also indicated that the IT authority from the senior layer, the IT management ability, IT experience and complementary resource investment all may bring influences to the values generated by IT. For example, the innovational IT investments of WMT and K-mart may produce different market value influences (Oh W, 2006, P.19-44).

\subsection{Exterior environment}

All activities of the enterprise are in certain exterior environment, so the impact of the exterior environment should be considered. In past researches, the industry is always taken as the control variable, but it is classified coarsely, and there are few researchers to study how the industrial character adjusts the IT investment value. First, the industry with strict competitive environment always adopts the IT investments which intention is to save the costs, and these investments will not obtain sustainable competitive advantage, and because of the competition, the welfare of this part will always be taken by consumers. Therefore, the industry should be defined more accurately to study which IT investment in the industry can produce higher return (Im K S, 2001, P.103-117 \& Dos Santos B L, 1993, P.1-23). Second, when the association among enterprises is close, the cooperative fellow can block or promote the implementation of the enterprise information system, so the relationships among organizations will influence the IT investment value. But there are few researches in this aspect, and there are some literatures studying ERP and IT outsourcing to take the supplier as one factor influencing abnormal return. Except for above two factors, the national culture and the infrastructure of the nation all can influence the IT investment value, but there is only one article to study this aspect up to now, and in this article, the author compared the differences of IT investment values in US and China, and the division about the country was only limited in the developing and developed countries, and only one country was selected as the representative, so the commonness of the conclusion needs to be further studied (Meng Z L, 2007, P.737-745).

\subsection{Risk factor}

In one latest article (Dewan S, 2007, P.370-394), the author had pointed out that when considering the influence of IT investment announcement, it should not only consider the rise of the return, but combine with the change of the risk, and the IT investment could influence the risk of the enterprise (Galbraith J R, 1977 \& Gurbaxani V, 1991\& Hunter L M, 2004, P.145-154). When the risk is not considered, the deflected result may be obtained. Dewan and Ren's research result indicated that when the system risk and the non-system risk of the enterprise changed, the abnormal return of the enterprise would not be significant (Dewan S, 2007, P.370-394). Therefore, in the future research design, the risk factor should be considered.

\subsection{Methodology}

The limitations of the methodology adopted in the research literatures include following aspects. First, past researches had pointed out that the occurrence of the event may increase the variance of the abnormal return, so the parameter test variables used in traditional statistical tests would always underestimate the variance to more easily reject the original hypothesis without abnormal return (Beaver W H, 1968, P.67-92 \& Kalay A, 1985, P.423-449 \& Boehmer E, 1991, P.253-272), but most literatures still adopted traditional statistical test method, and they had not considered the influence of the happening of the event on the variance of the abnormal return. Second, in most researches, the normal return mode was adopted as the market model, but the beta coefficient in the market model was obtained by the estimation window, and after the event happens, the beta coefficient of the enterprise may change, which will also influence the test of the abnormal return. Third, from domestic researches, Chinese financial market is different with the market in the developed country, so it should be serious to select and compare the normal return model, and the foreign market model should not be copied blindly.

\section{6 limitations of domestic researches}

Though China had introduced the event study method for a long time, the research about IT investment is still blank in China. In addition, as a developing country, China is very different with US about the IT infrastructure, the popularization degree of informationization, the culture and the consumption concept, so it should be further discuss whether the research conclusion in the US market could be applied in China. The IT investment and the informationization process of Chinese enterprises have their own characters, and the foreign research base can be used as references to further study Chinese IT investment.

From above discusses, the existing researches about the IT investment character, the organizational factor and the exterior environment are not sufficient, and there are few researches which can comprehensively consider above factors. In future researches, there are two research directions, and one is the vertical research which can pay attention to the IT investment character or the organizational factor or the exterior environment, and deeply study the influence of the 
dimension on IT investment value when controlling the variables in other two dimensions. The other is to comprehensively consider the influences of IT investment character, organizational factor and the exterior environment on the IT investment value in the research model, and the interactive influences among three aspects should not be ignored at the same time (Oh W, 2006, P.19-44). Except for above three aspects, the influences of the system risk and the non-system risk should also be considered when studying the IT investment value. Therefore, adding the risk into the research model as the control variable can more exactly measure the impact of the IT investment on the market value of the enterprise.

\section{Conclusions}

In this article, the empirical researches in past years about the impact of IT investment announcement on the enterprise market value were reviewed, and the result indicated that the IT investment needed certain environment to bring positive abnormal return. Based on the analysis of existing literatures and relative theoretical bases, these factors influencing the IT investment value can be divided into the IT investment character, the organizational factor and the exterior environment, and the limitations and the future research directions of each factor in existing researches were studied. Aiming at the disputes about the influences of IT investment on the enterprise market value and risk, and the methodology, the risk factors and the limitations in the current methodology were summarized. Through the analysis of these literatures, relative scholars can understand the status of these researches more clearly and develop their future works more favorably. Especially for Chinese scholars, because the status of foreign researches was completely analyzed in the article, they can use the research result in the article for references, and adopt Chinese sample data to develop their further researches aiming at the limitations in the current researches.

\section{References}

Agrawal M, Kishore R, \& Rao H R. (2006). Market reactions to E-business outsourcing announcements: An event study. Information \& Management, No. 43(7), P. 861-873.

Ang S, \& Cummings L L. (1997). Strategic response to institutional influences on information systems outsourcing. Organization Science, No. 8(3), P. 235-256.

Ball R, \& Brown P. (1968). An empirical evaluation of accounting income numbers. Journal of Accounting Research, No. 6(2), P. 159-178.

Banerjee A. (1992). A simple model of herd behavior. Quarterly Journal of Economics, No. 107(3), P. 797-817.

Barney J B. (1991). Firm resources and sustained competitive advantage. Journal of Management, No. 17(1), P. 99-120.

Barua A, Kriebel C H, \& Mukhopadhyay T. (1995). Information technologies and business value: An analytic and empirical investigation. Information Systems Research, No. 6(1), P. 3-23.

Barua A, \& Mukhopadhyay T. (2000). Information Technology and Business Performance: Past, Present and Future. In: Zumd R W(Ed), Framing the Domains of IT Management: Projecting the Future through Past. Pinnaflex Educational Resources, Cincinnnati, OH, P. 65-84.

Beaver W H. (1968). The information content of annual earnings announcements. Journal of Accounting Research (supplement), No. 6, P. 67-92.

Bharadwaj A S. (2000). A resource-based perspective on information technology capability and firm performance: An empirical investigation. MIS Quarterly, No. 24(1), P. 169-197.

Boehmer E, Musumeci J, \& Poulsen J T. (1991). Event-study methodology under conditions of event-induced variance. Journal of Financial Economics, No. 30, P. 253-272.

Brealey R A, \& Mysers S C. (1991). Principles of corporate finance. 4th ed. McGraw-Hill.

Brown S J, \& Warner J B. (1980). Measuring security price performance. Journal of Financial Economics, No. 8(3), P. 205-258.

Brown S J, \& Warner J B. (1985). Using daily stock returns: The case of event studies. Journal of Financial Economics, No.14(1), P. 3-31.

Campbell John Y, Andrew W L, \& MacKinlay A C. (1997). The Econometrics of Financial Markets. Princeton: Princeton University Press.

Chatterjee D, Pacini C, \& Sambamurthy V. (2002). The shareholder-wealth and trading-volume effects of information-technology infrastructure investments. Journal of Management Information Systems, No.19(2), P. 7-42.

Chatterjee D, Richardson V J, \& Zmud R W. (2001). Examining the shareholder wealth effects of announcements of newly created CIO positions. MIS Quarterly, No. 25(1), P. 43-70.

Chen H M, \& Chen X M. (2002). Event Response to Securities Price (in Chinese). Economic Research Journal, No.1, P. 40-47. 
Coase R H. (1937). The nature of the firm. Economica, No. 4(4). P. 386-405.

Cowan A R, \& Sergeant A M A. (1996). Trading frequency and event study test specification. Journal of Banking \& Finance, No. 20, P. 1731-1757.

Dahlman C J. (1979). The problem of Externality. Journal of Law and Economics, No. 22(1), P. 141-162.

Dardan S, Stylianou A, \& Kumar R. (2006). The impact of custmer-related IT investment on custmer satisfaction and shareholder returns. Journal of Computer Information Systems, No. 47(2), P. 100-111.

Davenport T H. (1993). Process Innovation: Reengineering Work through Information Technology. Boston: Harvard Business School Press.

Dehning B, Richardson V J, \& Zmud R W. (2003). The value relevance of announcements of transformational information technology investments. MIS Quarterly, No. 27(4), P. 637-656.

Dehning B, Richardson V J, Urbaczewski A, \& Wells J D. (2004). Reexamining the value relevance of e-commerce initiatives. Journal of Management Information Systems, No. 21(1), P. 55-82.

Dewan S, Ren F. (2007). Risk and return of information technology initiatives: Evidence from electronic commerce announcements. Information Systems Research, No. 18(4), P. 370-394.

Dixit A K, \& Pindyck R S. (1994). Investment under Uncertainty. Princeton: Princeton University Press.

Domsetz H. (1988). The theory of the firm revisited. Journal of Law, Economics \& Organization, No. 4(1), P. 141-161.

Dos Santos B L, Peffers K, \& Mauer D C. (1993). The impact of information technology investment announcements on the market value of the firm. Information Systems Research, No.4(1), P. 1-23.

Fama E F. (1970). Efficient capital markets: A review of theory and empirical work. Journal of Finance, No. 25, P. $383-417$.

Fama E F. (1976). Foundations of Finance. New York: Basic Books.

Ferguson C, Finn F, \& Hall J. (2005). Electronic commerce investments, the resource-based view of the firm and firm market value. International Journal of Accounting Information Systems, No. 6(1), P. 5-29.

Galbraith J R. (1977). Organization Design. Reading, MA: Addison-Wesley.

Gurbaxani V, \& Whang S. (1991). The impact of information systems on organizations and markets. Communications of the ACM. No.34(1).

Hammer M, \& Champy J. (1993). Business Process Reengineering: A Manifesto for Business Revolution. New York: Harper Business.

Hayes D C, Hunton J E, \& Reck J L. (2000). Information systems outsourcing announcement: Investigating the impact on the market value of contract-granting firm. Journal of Information Systems, No. 14(2), P. 109-125.

Hayes D C, Hunton J E, \& Reck J L. (2001). Market reaction to ERP implementation announcements. Journal of Information Systems, No.15(1), P. 3-18.

Holthausen R W, \& Verrecchia R E. (1990). The effect of informedness and consensus on price and volume behavior. Accounting Review, No. 65(1), P. 191-208.

Hunter L M, Kasoufb C J, Celuch K J, \& Curry K A. (2004). A classification of business-to-business buying decisions: Risk importance and probability as a framework for e-business benefits. Industrial marketing management, No. 33(2), P. 145-154.

Im K S, Dow K E, Grover V. (2001). Research report: A reexamination of IT investment and the market value of the firm- An event study methodology. Information Systems Research, No. 12(1), P.103-117.

Jenson M. (1978). Some anomalous evidence regarding market efficiency. Journal of Financial Economics, No. 6, P. 95-101.

Kalay A, \& Loewenstein U. (1985). Predictable events and returns: The case of dividend announcements. Journal of Financial Economics, No.14, P. 423-449.

Kern T, \& Kreijger J. (2002). Exploring relationships in information technology outsourcing: The interaction approach. European Journal of Information Systems, No. 11(1), P. 3-19.

Kester W C. (1984). Today's options for tomorrow's growth. Harvard Business Review, No. 62(2), P.153-160.

Khallaf A, \& Skantz T R. (2007). The effects of information technology expertise on the market value of a firm. Journal of Information Systems, No. 21(1), P. 83-105.

Kulatilaka N, \& Marcus A J. (1988). A general formulation of corporate real options. Research in Finance, No.7, P.183-200. 
Kulatilaka N, \& Marcus A J. (1992). Project valuation under uncertainty: When does DCF fail. Journal of Applied Corporate Finance, No. 5(3), P. 92-100.

Lee H G, Cho D H, \& Lee S C. (2002). Impact of e-business initiatives on firm value. Electronic Commerce Research and Applications, No.1(1), P. 41-56.

Lee I H. (1998). Market crashes and informational avalanches. Review of Economic Study, No. 65(225), P. 741-759.

Lin J C, Jang W Y, \& Chen K J. (2007). Assessing the market valuation of e-service initiatives. International Journal of Service Industry Management, No.18(3), P. 224-245.

MacKinlay C A. (1997). Event studies in economics and finance. Journal of Economic Literature, No. 37(6), P.137-157.

McGrath R G.. (1997). A Real options logic for initiating technology positioning investments. Academy of Management Review, No. 22(4), P. 974-996.

Melville N, Kraemer K, \& Gurbaxani V. (2004). Review: Information technology and organizational performance: An integrative model of IT business value. MIS Quarterly, No. 28(2), P. 283-313.

Meng Z L, \& Lee S Y. (2007). The value of IT to firms in a developing country in the catch-up process: An empirical comparison of China and the United States. Decision Support Systems, No. 43(3), P. 737-745.

Mooney J G, Gurbaxani V, \& Kraemer P L. (1996). A process oriented framework for assessing the business value of information technology. The Data Base for Advances in Information Systems, No. 27(2), P. 68-81.

Mukhopadhyay T, \& Kekre S. (2002). Strategic and operational benefits of electronic integration in B2B procurement processes. Management Science, No. 48(10), P.1301-1313.

Myers S C. (1977). Determinants of corporate borrowing. Journal of Financial Economics, No. 5(2), P.147-176.

Nelson R R, \& Winter S G.. (1982). An Evolutionary Theory of Economic Change. Harvard: Harvard University Press.

Oh W, \& Gallivan M J. (2004). An empirical assessment of transaction risks of it outsourcing arrangement: An Event Study. In: Proceedings of the 37th Hawaii International Conference on System Sciences, 2004.

Oh W, Gallivan M J, \& Kim J W. (2006). The market's perception of the transactional risks of information technology outsourcing announcements. Journal of Management Information Systems, No. 22(4), P. 271-303.

Oh W, Kim J W, \& Richardson V J. (2006). The moderating effect of context on the market reaction to IT investment. Journal of Information Systems, No. 20(1), P. 19-44.

Peak D A, Windsor J C, \& Conover J. (2002). Risks and effects of IS/IT outsourcing: A securities market assessment. Journal of Information Technology Cases and Applications, No. 4(1), P. 6-33.

Peteraf M. (1993). The cornerstones of competitive advantage: A resource-based view. Strategic Management Journal, No. 14(1), P. 179-191.

Pfeffer J, \& Salancik G. (1978). The External Control of Organizations: A Resource Dependence Perspective. New York: Harper and Row.

Porter M E. (1985). Competitive Advantage: Creating and Sustaining Superior Performance. New York: Free Press.

Porter M E. (1991). Toward a dynamic theory of strategy. Strategic Management Journal, No.12(1), P. 95-117.

Radhakrishnana A, Zub X, \& Groverc V. (2008). A process-oriented perspective on differential business value creation by information technology: An empirical investigation. The International Journal of Management Science, No. 36(6), P. 1105-1125.

Ranganathan C, \& Brown C V. (2006). ERP investment and the market value of firms: Toward an understanding of influential ERP project variables. Information Systems Research, No. 17(2), P. 145-161.

Richardson V J, \& Zmud R W. (2002). The Value Relevance of Information Technology Investments Announcements: Incorporating Industry Strategic IT Role. In Proceedings of the 35th Hawaii International Conference on System Science. USA, Hawaii: 2002.

Sabherwal R, \& Sabherwal S. (2005). Knowledge management using information technology: Determinants of short-term impact on firm value. Decision Sciences, No. 36(4), P. 531-567.

Sabherwal R, \& Sabherwal S. (2007). How do knowledge management announcements affect firm value? A study of firms pursuing different business strategies. IEEE Transactions on Engineering Management, No. 54(3), P. 409-422.

Sambamurthy V, Bharadwaj A, \& Grover V. (2003). Shaping agility through digital options: Reconceptualizing the role of information technology in contemporary firms. MIS Quarterly, No. 27(2), P. 237-263.

Selznick P. (1949). TVA and the Grass Roots: A Study in the Sociology of Formal Organization. Berkeley: University of California Press. 
Soh C, Markus M L. (1995). How IT creates business value: A process theory synthesis. In: DeGross et al(eds), Proceedings of the 16th International Conference on Information Systems. Amsterdam, The Netherlands. P. 29-41.

Subramani M, \& Walden E. (2001). The impact of e-commerce announcements on the market value of firms. Information Systems Research, No. 12(2), P. 135-154.

Subramani M. (2004). How do suppliers benefit from IT use in supply chain relationships. MIS Quarterly, No. 28(1), P. 45-75.

Taudes A, Feurstein M, \& Mild A. (2000). Options analysis of software platform decisions: A case study. MIS Quarterly, No. 24(2), P. 227-244.

Thompson J D, \& McEwen W J. (1958). Organizational goals and environment: Goal-setting as an interaction process. American Sociological Review, No. 23, P. 23-31.

Thompson J D. (1967). Organizations in Action. New York: McGraw-Hill.

Trigeorgis L, \& Mason S P. (1987). Valuing managerial flexibility. Midland Corporate Finance Journal, No. 5(1), P. 14-21.

Trigeorgis L. (1988). A conceptual options framework for capital budgeting. Advances in Futures and Options Research, No. 3, P. 145-167.

Trigeorgis L. (1993). The nature of option interactions and the valuation of investments with multiple real options. Journal of Financial and quantitative Analysis, No. 28(1), P. 1-20.

Wade M \& Hulland J. (2004). Review: The resource-based view and information systems research: Review, extension, and suggestions for future research. MIS Quarterly, No. 28(1), P.107-142.

Watts R, Zimmerman J. (1986). Positive Accounting Theory. Englewood Cliffs: Prentice Hall.

Williamson O E. (1979). Transaction cost economics: The governance of contractual relations. Journal of Law and Economics, No.22, P. 233-261.

Williamson O E. (1985). The Economic Institutions of Capitalism: Firms, Markets, Relational Contracting. New York: Free Press.

Ziebart D A. (1990). The association between consensus of beliefs and trading activity surrounding earnings announcements. Accounting Review, No. 65, P. 477-488. 